Research Article

\title{
Differences of Vitamin D Level in Non-pregnant Reproductive Age Women and First Trimester Pregnant Women
}

\author{
Perbedaan Kadar Vitamin D pada Perempuan Usia Reproduksi Tidak Hamil \\ dan Perempuan Hamil Trimester Pertama
}

\author{
Department of Obstetrics and Gynecology \\ Faculty of Medicine Universitas Padjajaran \\ Dr. Hasan Sadikin General Hospital
}

Rizkar A. Sukarsa, Radiastomo S. Budi, Benny H. Purwara, Hanom H. Syam

Bandung

\begin{abstract}
Objective : To compare vitamin D level in non-pregnant reproductive age women and first-trimester pregnant women.

Methods : This was acomparative cross-sectional study. The vitamin $D$ serum level of two groups, the first one wasnon-pregnant reproductive age women (18-35 years), and the second one was first-trimester pregnant women,was collected. Samples were examined by Electro Chemiluminescence Immunoassay (ECLIA) method. The study was conducted in Dr. Hasan Sadikin Hospital in February-April 2018.
\end{abstract}

Results : The mean of vitamin D level in the non-pregnant reproductive age women group was 18.73 (6.93) ng/mL, while the first-trimester pregnant women group was 13.87 (4.04) $\mathrm{ng} / \mathrm{mL}$. The difference in mean of vitamin $D$ level in both groups was significant with $p$-value $<0.001$.

Conclusions : Vitamin D level in the non-pregnant reproductive age women group is higher than the firsttrimester pregnant women group.

Keywords : first-trimester pregnant women, non-pregnant reproductive-age women, vitamin $\mathrm{D}$.

\begin{abstract}
Abstrak
Tujuan : Membandingkan kadar vitamin D pada perempuan usia reproduksi tidak hamil danperempuan hamil trimester pertama sehingga dapat mencegah berbagai komplikasi kehamilan.
\end{abstract}

Metode : Penelitian analitik komparatif potong lintang terhadap 60 perempuan yang dibagi menjadi 2 kelompok, kelompok perempuan usia reproduksi tidak hamil (18-35 tahun) dan kelompok perempuan hamil trimester pertama. Pada kedua kelompok dilakukan pemeriksaan kadar vitamin $D$ dengan metode Electro-chemiluminescence immunoassay(ECLIA). Penelitian ini dilakukan di RSUP Dr. Hasan Sadikin pada bulan Februari-April 2018.Data diproses menggunakan program SPSS versi 24.0.

Hasil : Kadar vitamin D rata-rata pada kelompok perempuan usia reproduksi tidak hamil adalah $18,73(6,93) \mathrm{ng} / \mathrm{mL}$, sedangkan pada kelompok perempuan hamil trimester pertama adalah $13,87(4,04) \mathrm{ng} / \mathrm{mL}$. Perbedaan kadar ratarata vitamin $D$ pada kedua kelompok tersebut bermaka dengan nilai $p<0,001$.

Kesimpulan : Kadar vitamin D pada kelompok perempuan usia reproduksi tidak hamil lebih tinggi dibandingkan dengan kelompok perempuan hamil trimester pertama.

Kata kunci : perempuan hamil trimester pertama, perempuan usia reproduksi tidak hamil, vitamin D.

Correspondence author: Rizkar A Sukarsa; morizarev@gmail.com

\section{INTRODUCTION}

Vitamin $D$ is a fat-soluble vitamin that plays an important role in overall health. Vitamin D deficiency is widespread among women worldwide, particularly in Indonesia and Malaysia, with the prevalence up to $63 \%$. Approximately 504 ofreproductive age women (18-40 years) is found the mean of 25 -hydroxy-vitamin $D(25[\mathrm{OH}]$ D) serum level is $48 \mathrm{nmol} / \mathrm{L} .{ }^{1}$ Forty-eight percent of first trimester pregnant women in US also have vitamin D deficiency, with the mean of $25(\mathrm{OH}) \mathrm{D}$ serum level is $40 \mathrm{nmol} / \mathrm{L}^{2}$ Vitamin $D$ deficiency has been widely discussed as a health problem that affects not only musculoskeletal health but also the problem of acute and chronic diseases as well as an increased risk of cancer, autoimmune disease, diabetes, and cardiovascular disease. ${ }^{3}$

Vitamin D deficiency is defined as 25-hydroxy- 
vitamin $D$ serum level< $20 \mathrm{ng} / \mathrm{mL}(50 \mathrm{nmol} / \mathrm{L})$, while vitamin $D$ insufficiency is vitamin $D$ serum level $21-29 \mathrm{ng} / \mathrm{mL}(52-72 \mathrm{nmol} / \mathrm{L}) .{ }^{4}$ Factors that affect vitamin $D$ deficiency in non-pregnant reproductive age women and first trimester pregnant women include the changes of organ functions involved in the synthesis of $25(\mathrm{OH}) \mathrm{D}$ such as skin, liver, kidney, and intestines; lifestyle that tend to avoid sunlight; use of sunscreen; and low intake of foods containing vitamin $\mathrm{D}$. Whereas in these groups need to get attention because they are vulnerable to nutritional problems due to the physiological role of menstruation and childbirth. ${ }^{5}$ Increased Body Mass Index (BMI) is also another factor that can affect vitamin $D$ levels. ${ }^{6}$

The effect of vitamin $D$ on muscle strength and muscle function has been shown in various studies of skeletal muscles in animals and humans. Pelvic floor weakness can manifest clinically in symptoms of pelvic floor dysfunction, including urinary incontinence, faecal incontinence, and pelvic organ prolapse. Thus there appears to be a relationship between the low serum vitamin D concentration which causes reduced skeletal muscle mass and muscle strength. The clinical relation of vitamin $\mathrm{D}$ deficiency and pelvic floor disorders is thought to be due to reduced skeletal muscle mass and muscle strength throughout the body, including the pelvic floor muscles of pelvis. $^{7}$

Study shows that most of the reproductive age women in Indonesia have vitamin D deficiency. ${ }^{8}$ Pregnancy and childbirth causes damage to the pelvic muscles due to stretching some pelvic muscles. After the birth, the pelvic muscles damaged need to repair, for about 3 months. Various causes influence the healing of pelvic muscles, and one of them is vitamin D level in reproductive age women and first trimester pregnant. Providing vitamin D supplementation tonon-pregnant reproductive age women and first trimester pregnant are not routinely given in
Indonesia. The normal value of vitamin $D$ levels in non-pregnant reproductive age women and first trimester pregnant in Indonesia remains unknown. In addition, study on the cause of vitamin $D$ deficiency has never been done in Indonesia.

Considering these problems, this study aimed to compare vitamin $D$ level in non-pregnant reproductive age women and first-trimester pregnant women in order to prevent some complications in pregnancy and the pelvic floor weakness, both in non-pregnant reproductive age women and pregnant women.

\section{METHODS}

This was a comparative cross-sectional study. Subjects were non-pregnant reproductive-age women in Bandung and first-trimester pregnant women (18-35 years) in Dr. Hasan Sadikin Hospital Bandung with a timeline of February to April 2018. Samples were collected by consecutive sampling. The total population were 60 women, divided into two groups: 30 non-pregnant reproductive age women, and 30 first trimester pregnant women that match the inclusion and exclusion criteria.

The inclusion criteria were age 18-35 years old, BMI $18-30 \mathrm{~kg} / \mathrm{m}^{2}$, have no vitamin D supplementation, no smoking, exposed to sunlight between 8.00-3.00 p.m, have no chronic illness and malignancy. The exclusion criteria were women who did not continue the examination and those who were not included in the inclusion criteria.

Blood sample of vitamin D from subjects was collected and examined by Electrochemiluminescence immunoassay (ECLIA) method.

Data were analyzed by T-test and processed with the help of Statistical Product and Service Solutions (SPSS) for Windows version 24.0. 


\section{RESULT}

Table 1. Characteristics of Age, BMI, Calories Intake, and Sunlight Exposure in both Groups

\begin{tabular}{|c|c|c|c|}
\hline \multirow[b]{2}{*}{ Characteristics } & \multicolumn{2}{|c|}{ Groups } & \multirow[b]{2}{*}{ P-Value } \\
\hline & $\begin{array}{l}\text { Non-pregnant } \\
\text { reproductive-age women } \\
\qquad(n=30)\end{array}$ & $\begin{array}{l}\text { First-trimester pregnant } \\
\text { women } \\
(n=30)\end{array}$ & \\
\hline \multicolumn{4}{|l|}{ Age (year) } \\
\hline Mean (SD) & $23.9(4.6)$ & $25.7(4.6)$ & \\
\hline Median & 21.5 & 26.5 & $0.153^{*}$ \\
\hline Range & $19-34$ & $19-34$ & \\
\hline \multicolumn{4}{|l|}{ BMI (kg/m2) } \\
\hline Mean (SD) & $22.6(2.8)$ & $23.8(3.1)$ & \\
\hline Median & 21.9 & 24.4 & \\
\hline Range & $18.3-29.9$ & $18.7-29.5$ & $0.101^{* *}$ \\
\hline \multicolumn{4}{|c|}{ Calories intake (kcal) } \\
\hline Mean (SD) & $2053.3(179.5)$ & 2223.3(170.6) & \\
\hline Median & 2050 & 2250 & \\
\hline Range & $1700-2500$ & $1800-2500$ & $<0.001^{* *}$ \\
\hline \multicolumn{4}{|c|}{ Sunlight exposure (minute) } \\
\hline Mean (SD) & $18.0(4.1)$ & $17.7(3.4)$ & \\
\hline Median & 20 & 17.5 & $0.736^{*}$ \\
\hline Range & $10-25$ & $10-25$ & \\
\hline
\end{tabular}

Interpretation : Calories intake in first trimester pregnant women was higher than non-pregnant reproductive age women $(p<0.05)$, *analyzed by Mann-Whitney; ** analyzed by unpaired t-test.

Table 2. Differences of Vitamin D Level in both Groups

\begin{tabular}{|c|c|c|c|}
\hline \multirow[b]{2}{*}{ Variable } & \multicolumn{2}{|c|}{ Groups } & \multirow[b]{2}{*}{ P-Value } \\
\hline & $\begin{array}{l}\text { Non-pregnant } \\
\text { reproductive-age women } \\
(n=30)\end{array}$ & $\begin{array}{l}\text { First-trimester pregnant } \\
\text { women } \\
(n=30)\end{array}$ & \\
\hline \multicolumn{4}{|l|}{ Vitamin D level (ng/ml) } \\
\hline Mean (SD) & $18.73(6.93)$ & $13.87(4.04)$ & \\
\hline Median & 17.58 & 12.34 & $0.004^{*}$ \\
\hline Range & $10.39-36.26$ & $8.48-24.65$ & \\
\hline \multicolumn{4}{|c|}{$\begin{array}{l}\text { Vitamin D level after calories } \\
\text { intake adjusted }\end{array}$} \\
\hline Mean (SE) & $19.71(1.03)$ & $12.89(1.03)$ & $<0.001^{* *}$ \\
\hline Confident interval 95\% & $17.64-21.78$ & $10.82-14.96$ & \\
\hline \multicolumn{4}{|l|}{ Vitamin D status } \\
\hline Deficiency $(<12)$ & 5 & 14 & \\
\hline Insufficiency (12-20) & 11 & 13 & $0.003^{* * *}$ \\
\hline Sufficiency (> 20) & 14 & 3 & \\
\hline
\end{tabular}

Interpretation:Vitamin D level in non-pregnant reproductive age women was higher than first-trimester pregnant women ( $p<0.001)$, *analyzed by Mann-Whitney; **analyzed by ; ***analyzed by Chi-square.

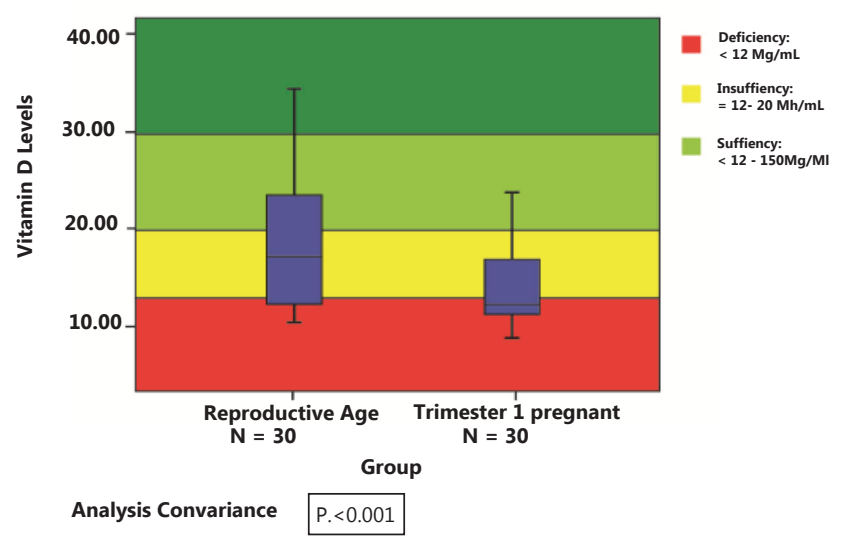

Figure 1. Differences of vitamin D level in non-pregnant reproductive age women and first-trimester pregnant women 


\section{Vitamin D level}

Our study showed that the significant difference of vitamin $D$ level in both groups ( $p<0.001$ ). Vitamin $D$ level in non-pregnant reproductive age women was 18.73 (6.93) $\mathrm{ng} / \mathrm{mL}$, while in the first-trimester pregnant women was 13.87 (4.04) $\mathrm{ng} / \mathrm{mL}$. The mean of vitamin $\mathrm{D}$ level both before and after calories intakeadjusted in nonpregnant reproductive age women was higher than first-trimester pregnant women. Based on vitamin $\mathrm{D}$ status, non-pregnant reproductive age women have vitamin D sufficiency $(46.7 \%)$, while first-trimester pregnant women have vitamin $D$ deficiency (46.7\%).

\section{DISCUSSION}

The characteristics of the subjects compared in this study were age, Body Mass Index (BMI), sunlight exposure and number of calories intake. This was based on the assumption that these factors can be confounding factors on the results of this study. So to be able to compare the two groups of studies, the characteristics of subjects between non-pregnant reproductive age women and first-trimester pregnant women must be homogeneous. It was found that there were no significant differences in the characteristics of the subjects, the age of patients $(p=0.153), B M I$ $(p=0.101)$ and duration of sunlight exposure $(p=0.736)$, while the number of calories intake $(p<0.001)$. This study concluded that both groups are homogeneous; thus, it was expected that bias due to age, BMI, and duration of sunlight exposure could be removed so that both groups could be compared.

The number of calories intake in this study was similar to the study suggested that non-pregnant reproductive age women have a daily calorie intake of 1,800-2,000 kcal for mild daily activities and 2,000-2,200 for moderate to heavy daily activities. In the first trimester pregnant women, the need for daily caloric intake increases by 150$200 \mathrm{kcal}$. This is caused by rapid fetal formation needs. ${ }^{9}$

\section{Vitamin D Level in Non-pregnant Reproductive Age Women and First-Trimester Pregnant Women}

The mean of vitamin $D$ level in non-pregnant reproductive age women in this study was found to be significantly higher than first-trimester pregnant women. All subjects in this study had vitamin $D$ level below normal $(<30 \mathrm{ng} / \mathrm{mL})$.

Vitamin D has an important role in calcium homeostasis as well as bone development and mineralization. Exposure to ultraviolet B (290-320 $\mathrm{nm}$ ) is the main source of vitamin D. ${ }^{10}$ For bone health, at least the level of 25-hydroxy-vitamin D3 $20 \mathrm{ng} / \mathrm{mL}$ is needed. ${ }^{11}$ Vitamin D deficiency is very common however, the magnitude of D hypovitaminosis could vary depending on the population studied, regional and seasonal considerations. Study in US found that the prevalence of vitamin $D$ deficiency in nonpregnant reproductive age women was $52 \%$ up to $87 \%$ in winter and depends on height. ${ }^{12}$ In a systematic review of 195 studies conducted in 44 countries with participants of approximately 168,000 people, the mean of 25-hydroxy-vitamin D3 serum level was $<20 \mathrm{ng} / \mathrm{mL}$ for about $37.3 \%$ of the study subjects. Vitamin D deficiency in African-American, Turkish, and Chinese were $42.4 \%, 81.4 \%$, and $79.7 \%$, respectively. ${ }^{13}$

Vitamin D deficiency is a factor in the pathophysiology of several types of cancer, cardiovascular disease, hypertension, diabetes and morbidity in pregnancy. ${ }^{4,14-16}$ Data from the 2005-2006 NHANES survey showed that 69\% of pregnant women and $78 \%$ of non-pregnant reproductive age women in $U$ had levels of 25hydroxy-vitamin D3 $<30 \mathrm{ng} / \mathrm{mL}$. In pregnancy, the placenta is an extra-renal source of calcitriol $\left(1,25\right.$-dihydroxy-vitamin D). ${ }^{12}$

In 504 women of childbearing age (WUS) aged 18-40 years found that serum concentrations of 25-hydroxy-vitamin D3 were $48 \mathrm{ng} / \mathrm{mL}$ with a prevalence of vitamin D deficiency of $63 \%$. As many as $63 \%$ of WUS in Jakarta aged $18-40$ years have vitamin $D$ deficiency with the mean level of 25-hydroxy-vitamin D3 concentration of 19.2 $\mathrm{ng} / \mathrm{mL}$. IIt was found that vitamin $\mathrm{D}$ deficiency can be caused by lifestyle tend to avoid sunlight exposure, use of sunscreen and low food intake of vitamin D. People who live near the equator exposed to sunlight without using a kind of sunscreen protector have 25-hydroxy-vitamin D3 level $>30 \mathrm{ng} / \mathrm{mL}^{1,17}$

Vitamin D is deposited mainly in adipose tissue and muscle. Vitamin $D$ has been detected in different adipose tissue compartments, such as 
the subcutaneous abdomen, omental, pericardial and perirenal. ${ }^{18,}{ }^{19} \mathrm{High}$-fat levels can also cause low levels of vitamin $D$ in the circulation due to the trapping of vitamin $D$ in fat cells. ${ }^{20} \mathrm{~A}$ study found that $70.4 \%$ of obese women had $25(\mathrm{OH}) \mathrm{D}$ circulation between 25 and $75 \mathrm{nmol} / \mathrm{L}$, compared to $86.1 \%$ of reproductive-age women. ${ }^{21}$ Obese women had $25(\mathrm{OH}) \mathrm{D}$ lower than normal-weight women in the first trimester of pregnancy. Similarly, a study by Bodnar et al. found that obese women (based on pre-pregnant BMI) had lower serum concentrations of $25(\mathrm{OH}) \mathrm{D}$ compared to normalweight women in first-trimester pregnancy. ${ }^{22}$

Pregnancy can increase the concentration of Vitamin D Binding Protein (VDBP) in circulation. Estrogen metabolism can be disrupted in obese women, and this can potentially affect hepatic production of VDBP. Circulating VDBP concentrations are influenced by the VDBP phenotype, and a relationship between DBP, gene polymorphism, and fat mass has been demonstrated. In an in vitro study, interleukin- 6 (IL-6) increases the expression of messenger ribonucleic acid (mRNA) inside, and VDBP secretion from hepatic cells. Higher levels of circulating IL- 6 in obese women are found and could possibly affect DBP hepatic production. Interestingly, DBP concentrations are positively associated with serum lipids and high sensitive C-reactive protein (hs-CRP). ${ }^{18}$ The possible reason for low 25(OH)D in first-trimester pregnant women is low vitamin $D$ intake. In a food intake survey by Riksmaten showed that intake of vitamin $D$ in women, the age group of 18-30 years and 31-44 years was 5.2 and $6.2 \mu \mathrm{g} /$ day respectively. ${ }^{18}$

Concentrations of $1 \mathrm{a}, 25-(\mathrm{OH}) 2 \mathrm{D}$ and DBP circulation increase during pregnancy. 1a,25$(\mathrm{OH}) 2 \mathrm{D}$ increases due to increased renal 1ahydroxylase activity and increased DBP due to increased estrogen levels that affect hepatic production. Both VDR and the enzymes responsible for converting $25(\mathrm{OH}) \mathrm{D}$ to $1 \mathrm{a}, 25$ $(\mathrm{OH}) 2 \mathrm{D}$ are present in the placenta, making it at least have an autocrine or paracrine effect. In observational studies, low vitamin D levels during pregnancy have been associated with an increased risk of preeclampsia, diabetes mellitus in pregnancy, and fetal growth restriction. ${ }^{18}$

The limitation in this study was the mean of vitamin D level in the population in Southeast Asia, especially in Indonesia, was still very limited, so there was no reference value for vitamin D levels for the mean of vitamin $D$ level in Indonesian women. This study was cross-sectional, so it could not be concluded about the causes of differences in vitamin D levels in both groups. Further study was needed in the form of longitudinal studies that assess differences in vitamin $D$ levels by giving vitamin $\mathrm{D}$ supplementation.

\section{CONCLUSION}

Vitamin $D$ level in non-pregnant reproductiveage women is higher than first-trimester pregnant women.

\section{REFERENCES}

1. Yosephin B, Khomsan A, Briawan D, Rimbawan R. Vitamin $D$ plus calcium supplementation increased serum $25(\mathrm{OH}) \mathrm{D}$ on reproductive-age women workers. Asian Pac J Trop. 2015;5(11):877-80.

2. Bischoff-Ferrari, Kiel, Dawson-Hughes, Orav, Li, Spiegelman, et al. Dietary calcium and serum 25hydroxyvitamin D status in relation to BMD among U.S. adults. Journal of bone and mineral research : the official J Am Soc Bone Mineral Research. 2009;24(5):935-42.

3. Aleyasin, Hosseini, Mahdavi, Safdarian, Fallahi, Mohajeri, et al. Predictive value of the level of vitamin $D$ in follicular fluid on the outcome of assisted reproductive technology. Eur J Obstet Gynecol Reprod Biol. 2011;159(1):132-7.

4. Luk, Torrealday, Perry, Pal. Relevance of vitamin D in reproduction. Hum Reprod. 2012;27(10):3015-27.

5. Bolland, Grey, Ames, Horne, Mason, Wattie, et al. Age, gender, and weight-related effects on levels of 25-hydroxyvitamin $D$ are not mediated by vitamin $D$ binding protein. Clin Endocrinol. 2007;67(2):259-64.

6. Kull, Kallikorm, Lember. Body mass index determines sunbathing habits: implications on vitamin $D$ levels. Internal Med J. 2009;39(4):256-8.

7. Aydogmus, Kelekci, Aydogmus, Demir, Yilmaz, Sutcu. Association of antepartum vitamin D levels with postpartum pelvic floor muscle strength and symptoms. Int Urogynecol J. 2015;26(8):1179-84.

8. Normala. Perbandingan kadar 25-hidroksi vitamin D3 serum antara penderita prolaps organ panggul dengan non prolaps organ panggul pada perempuan menopause. Bandung: Padjadjaran University; 2017;115.

9. Mottola, Giroux, Gratton, Hammond, Hanley, Harris, et al. Nutrition and exercise prevent excess weight gain in overweight pregnant women. Med Sci Sports Exercise. 2010;42(2):265-72. 
10. Mackawy, Al-Ayed, Al-Rashidi. Vitamin d deficiency and its association with thyroid disease. Int J Health Sci 2013;7(3):267-75.

11. De-Regil, Palacios, Ansary, Kulier, Pena-Rosas. Vitamin D supplementation for women during pregnancy. The Cochrane database of systematic reviews. 2012(2):Cd008873.

12. Ginde, Sullivan, Mansbach, Camargo. Vitamin D insufficiency in pregnant and nonpregnant women of childbearing age in the United States. Am J Obstet Gynecol. 2010;202(5):436.e1-8.

13. Hilger, Friedel, Herr, Rausch, Roos, Wahl, et al. A systematic review of vitamin $D$ status in populations worldwide. Bri J Nut. 2014;111(1):23-45.

14. Grundmann, von Versen-Höynck. Vitamin D - roles in women's reproductive health? Reprod Biol Endocrinol. 2011;9(1):146.

15. Lerchbaum, Obermayer-Pietsch. Vitamin D and fertility: a systematic review. Eur J Endocrinol. 2012;166(5):76578.

16. Aloia. Clinical Review: The 2011 report on dietary reference intake for vitamin D: where do we go from here? J Clin Endocrinol Metabol. 2011;96(10):2987-96.
17. Green, Skeaff, Rockell, Venn, Lambert, Todd, et al. Vitamin D status and its association with parathyroid hormone concentrations in women of child-bearing age living in Jakarta and Kuala Lumpur. Eur J Clin Nut. 2008;62(3):373-8.

18. Karlsson. Vitamin D in women of reproductive age and during pregnancy-Focus on intake, status and adiposity. 2013;3-8.

19. Blum, Dolnikowski, Seyoum, Harris, Booth, Peterson, et al. Vitamin D(3) in fat tissue. Endocrine. 2008;33(1):90-4.

20. Moy, Bulgiba. High prevalence of vitamin D insufficiency and its association with obesity and metabolic syndrome among Malay adults in Kuala Lumpur, Malaysia. BMC public health. 2011;11:735.

21. Hultin, Edfeldt, Sundbom, Hellman. Left-shifted relation between calcium and parathyroid hormone in obesity. J Clin Endocrinol Metabol. 2010;95(8):3973-81.

22. Bodnar, Catov, Roberts, Simhan. Prepregnancy obesity predicts poor vitamin $D$ status in mothers and their neonates. J Nut. 2007;137(11):2437-42. 